\title{
Improving perception, attitude and interest in medical leadership and management - a novel model proposed by medical students
}

This article was published in the following Dove Press journal:

Advances in Medical Education and Practice

\author{
Owais Ali Shah \\ Mohammed Khalid Aslami \\ Amir-Humza Tahir Suleman \\ Faculty of Medicine, St. George's \\ Hospital Medical School, London, UK
}

Correspondence: Mohammed Khalid

Aslami

Faculty of Medicine, St. George's Hospital Medical School, Cranmer Terrace, London SWI7 ORE, UK

Email kha.aslamil@gmail.com

\section{Dear editor}

After reading the article by Rouhani et $\mathrm{al}^{1}$ with great interest, we agree that the level of medical leadership and management (MLM) training in the UK medical schools could be improved massively. As fellow medical students, we would like to offer our perspective on how universities can better implement MLM teaching into curricula to effectively mould future clinician leaders within an ever-expanding National Health Service.

As reported, the General Medical Council provides curriculum guidance for medical schools based on the skills identified in the Medical Leadership Competency Framework (MLCF). ${ }^{1}$ In line with the findings of the authors, a study showed that only $56 \%$ of the responding universities incorporate MLCF into their curriculum, and remarkably, $81.9 \%$ of students were unaware of the MLCF. ${ }^{2}$ This can lead to a lack of insight and awareness into MLM among medical students possibly leading to reluctance in pursuing MLM roles in the future.

Lessons can be learnt from Cambridge University which more than tripled its output of general practitioner trainees in 2016 after adopting increased student exposure to general practice. ${ }^{3}$ Keeping this in mind, we would like to propose a novel 3-step model for universities to incorporate MLCF into existing curricula comprising early exposure, consolidation and application.

The focus in early years of medical school should be to introduce MLM through lectures and events, inviting well-known organizations involved in MLM to deliver interactive sessions with an aim to provide early exposure to opportunities available in this diverse and important field. Consolidation phase can be achieved through case-based discussions and focus groups. During clinical years, the focus should shift toward application - keeping the challenges of an overcrowded curriculum in mind, we suggest utilizing existing opportunities like student-selected components. Such projects have been shown to enhance the perception of leadership and management among students. ${ }^{4}$ Furthermore, student prizes and awards can be used as incentives to trigger student interest in these projects. By the time the students graduate, they will be better prepared to get involved in MLM and transfer these skills to deliver safe and effective patient care. This stepwise approach fits in line with Kolb's cyclical model of learning, consisting of experimental learning, reflection, forming abstract concepts and testing them in new situations. ${ }^{5}$

We congratulate the authors on completing an insightful multi-institutional study exploring medical student views on MLM. We must stress, however, that Sheffield, 
Aberdeen and Nottingham represented $67.5 \%$ of a small overall response rate. ${ }^{1}$ We also feel that the addition of student demographics such as age and gender could have provided for interesting subgroup analysis. We agree that the emphasis on the importance of MLM in medical schools can be improved, and we feel that the implementation of the proposed model can provide a possible mean to achieve this. Currently, the topic of MLM is introduced very late on, but by early exposure followed by consolidation and a gradual switch to its application, it will become an integral component of a doctor's skillset.

\section{Disclosure}

The authors report no conflict of interest in this communication.

\section{References}

1. Rouhani MJ, Burleigh EJ, Hobbis C, et al. UK medical students' perceptions, attitudes, and interest toward medical leadership and clinician managers. Adv Med Educ Pract. 2018;9:119-124.

2. Stringfellow TD, Rohrer RM, Loewenthal L, et al. Defining the structure of undergraduate medical leadership and management teaching and assessment in the UK. Med Teach. 2015;37(8):747-754.

3. David Millet. Medical school tripled GP trainee output after raising exposure to general practice. GPonline. 2017 [cited March 13, 2018]. Available from: https://www.gponline.com/medical-school-tripledgp-trainee-output-raising-exposure-general-practice/article/1423692. Accessed March 13, 2018.

4. Al-Talib M, McLernon-Billows D, Poore S, Bloomfield D. Engaging medical students in leadership and quality improvement through a formal educational programme. MedEdPublish. 2016 [cited March 13, 2018]. Available from: http://www.mededpublish.org/manuscripts/562/v1. Accessed March 13, 2018.

5. Kolb DA. Experiential Learning: Experience as the Source of Learning and Development. Englewood Cliffs: Prentice Hall Inc; 1984.

Dove Medical Press encourages responsible, free and frank academic debate. The content of the Advances in Medical Education and Practice 'letters to the editor' section does not necessarily represent the views of Dove Medical Press, its officers, agents, employees, related entities or the Advances in Medical Education and Practice editors. While all reasonable steps have been taken to confirm the content of each letter, Dove Medical Press accepts no liability in respect of the content of any letter, nor is it responsible for the content and accuracy of any letter to the editor.

\section{Publish your work in this journal}

Advances in Medical Education and Practice is an international, peerreviewed, open access journal that aims to present and publish research on Medical Education covering medical, dental, nursing and allied health care professional education. The journal covers undergraduate education, postgraduate training and continuing medical education including emerging trends and innovative models linking education, research, and health care services. The manuscript management system is completely online and includes a very quick and fair peer-review system. Visit http://www.dovepress.com/testimonials.php to read real quotes from published authors. 